$m u s$, were numerous in midsummer. Zooplankton never represented a significant portion of the total plankton.

\section{Literature Cited}

Allen, W. E. 1920. A quantitative and statistical study of the plankton of the San Joaquin River and its tributaries in and near Stockton, California, in 1913. Univ. California, Pub1. Zool. 22: 1-292.

Blum, J. L. 1956. The ecology of river algae. Botan. Rev. 22: 291-341.

Brirlzy, F. J., and L. J. Katzin. 1942. Distribution of stream plankton in the Ohio River System. Am. Midland Naturalist 27: 177-190.

California Department of Water Resources. 1962. Sacramento River water pollution survey. Bull. 111, 100 p.; Appendix C, 175 p.

Coffing, Charlene. 1937. A quantitative study of the phytoplankton of the White River Canal, Indianapolis, Indiana. Butler Univ., Botan. Stud. 4: 13-31.

des Cilleuls, J. 1926. Le phytoplancton de la Loire. Compt. Rend. Acad. Sci. (Paris) 182: 649-651.

- . 1928. Revue générale des études sur le plancton des grands fleuves ou rivières. Int. Rev. Ges. Hydrobiol. Hydrogr. 20: 174-206.

Galtsoff, P. S. 1924. Limnological observations of the upper Mississippi, 1921. Bull. U. S. Bur. Fish. 39: 347-438.

Greenberg, A. E. 1962. Stream plankton data presentation. Water and Sewage Works 109: 458.

Hutchinson, G. E. 1943. Thiamin in lake waters and aquatic organisms. Arch. Biochem. 2: 143-150.

Hutchinson, G. E., and Jane K. Setlow. 1946. Limnological studies in Connecticut. VIII. The niacin cycle in a small inland lake. Ecology 27: 13-22.

Kofoid, C. A. 1903. The plankton of the Illinois River, 1894-1899, with introductory notes upon the hydrography of the Illinois River and its basin. Part I. Quantitative investigations and general re- sults. Bull. Illinois State Lab. Nat. Hist. 6: 95-629. 1908. The plankton of the Illinois River, 18941899. Part II. Constituent organisms and their seasonal distribution. Bull. Illinois State Lab. Nat. Hist. 8: 1-361.

Lackey, J. F., Elsie Wattie, J. F. Kachmar, and O. R. Flacak. 1943. Some plankton relationships in a small unpolluted stream. Am. Midland Naturalist 30: $403-425$.

Pennak, R. W. 1946. The dynamics of fresh-water plankton populations. Ecol. Monographs 16: 339-355.

Reinhard, E. G. 1931. The plankton ecology of the upper Mississippi, Minneapolis to Winona. Ecol. Monographs 1: 395-464.

Rice, C. H. 1938. Studies in the phytoplankton of the River Thames (1928-1932). I. Ann. Bot. n.s. 2: 539557.

Roach, L. S. 1932. An ecological study of the plankton of the Hocking River. Bull. Ohio Biol. Survey 5: 253-279.

Rohde, Wilhelm. 1948. Environmental requirements of fresh-water plankton algae. Symb. Bot. Upsal. 10: $1-149$.

Schröder, B. 1899. Das pflanzliche Plankton der Oder. Forschungber. Biol. St. Plon. 7: 15-24.

Southern, R., and A. C. Gardiner. 1938. Reports from the Limnological Laboratory. IV. Phytoplankton of the River Shannon and Loch Derg. Proc. Royal Irish Acad. 45: 89-124.

U. S. Dept. Health, Education, and Welfare, Public Health Service. 1959. National Water Quality Network. Annual compilation of data, Oct. 1, 1958-Sept. 30, 1959. P.H.S. Publ. 663, 323 p.

Walker, Helen M., and J. Lev. 1953. Statistical inference. Henry Holt, New York. 510 p:

Wundsch, H. H. 1920. Beiträge zur Frage nach dem Einfluss von Temperatur und Ernährung auf die quantitative Entwicklung von Süsswasser Organismen. Zool. Jahrb. Abt. f. allg. Zool. u. Physiol. 38: $1-48$.

\title{
PRIMARY PRODUCTION AND THE DISAPPEARANCE OF DEAD VEGETATION ON AN OLD FIELD IN SOUTHEASTERN MICHIGAN
}

\author{
Richard G. WiegerT ${ }^{1}$ and Francis C. Evans \\ Department of Zoology, University of Michigan, Ann Arbor, Michigan
}

\section{INTRODUCTION}

In the absence of large-scale importation of organic debris, all organisms of a community above the level of the primary producers are ultimately dependent on the energy supplied by photosynthetic plants. The measurement of the rate of energy fixation by the vegetation thus provides a starting point for describing the functional aspects of an ecosystem, as opposed to a description of its structural composition. The present paper presents the results of an investigation of primary production on an old field in southeastern Michigan.

${ }^{1}$ Present address: Univ. of Georgia Laboratory of Radiation Ecology, Bldg. 772-G, SR00, Aiken, South Carolina.
Much has been written about the production of cropland and pasture as it relates to the energy supplied to man and his domestic animals. For harvested crops, the production is calculated from the yield taken from a unit area of land. When the product of photosynthesis is not harvested by man, the traditional measure of production has been the increase in standing crop during the growing season. In other words, the vegetation has been treated as though it were a crop, and the estimate of the "yield" obtained from sampling the peak standing crop has been equated with the net primary production on the area.

There are several criticisms of this approach. First, it ignores the possible growth-stimulating effects of moderate grazing, with a resultant in- 
crease in the total production. Second, it does not account for the mortality of green plants before the peak standing crop is attained (representing growth not measured by standing-crop determinations), nor does it measure the growth which may occur during the decline in standing crop after the peak. And third, it does not take into account the differences in the time at which different species attain their peak standing crop.

The first criticism will not be considered further in this paper, except to note that "grazing" by aboveground herbivores accounts for relatively little of the net primary production on the study area. It does not seem to be important in preventing the attainment of maturity by any of the vegetation components and therefore probably has little effect on their growth rates.

The second and third criticisms, however, will be dealt with in detail. The peak standing crop and the net primary production of the vegetation would be identical only where the vegetation was composed of individuals which stopped growing at a single instant in time, and where mortality occurred only during the post-growth period. Such a situation would normally be encountered only in the homogeneous stands of cultivated crops or in the early stages of natural succession on abandoned cropland. The latter situation commonly involves dominance by one or a few species of forbs; there may be little mortality before maturity and little growth afterwards. The fairly rapid diversification of the flora, with consequent differences in time of maturation of the various species, and the invasion of perennial grasses with growth and mortality occurring throughout the growing season, soon lead to a condition where the peak standing crop has little relation to the total production (Odum 1960).

This problem confronts all those who attempt to measure primary production in any but the simplest natural ecosystems. Even where the difficulty was recognized, lack of better methods has forced reliance on the procedure that equates net primary production with the annual change in biomass of the producer organisms, resulting in an underestimation of the actual net production. The present study was designed to provide both an accurate measurement of the net production of the diverse perennial vegetation of a southeastern Michigan old field and a method of measurement adaptable to production studies of similar vegetation types in other areas. We wish also to discuss some aspects of succession on the particular field involved, and to explore some of the problems encountered in measuring the disappearance rate of dead material, since a knowledge of this rate is essential to our method of estimating production.
The Area Studied

This study was conducted on the 15-acre Evans Old Field, located in the northeast quarter of section 19, Putnam Twp., Livingston Co., Michigan, within the Edwin S. George Reserve of the University of Michigan. The 1,200-acre reserve, originally farms, has been enclosed by a game fence since 1928 and allowed to revert to a "natural" condition, subject only to the disturbances caused by a herd of whitetail deer maintained within its boundaries.

The topography, soils, and vegetation of the field have been described in detail by Evans and Cain (1952) and Evans and Dahl (1955). Local relief is slight, with gentle contours and several shallow, poorly drained depressions or swales. The soil of the upland parts of the field is a graybrown podzolic sandy loam of the Fox series. This soil is porous and, in a well-drained area such as the Old Field, dries out quickly, especially with the low precipitation in the latter part of the growing season.

In the swales, the original soil profile has been covered by as much as $1 \mathrm{~m}$ of alluvial silt. These surface deposits in the swales retain considerably more moisture and have a higher organic content than the sandy soils of the uplands.

Studies of the vegetation of the field made in 1948 (Evans and Cain 1952) and again in 1953 (Evans and Dahl 1955) showed a diverse perennial flora. The swales supported a dense growth of Kentucky bluegrass (Poa pratensis), interspersed with milkweed (Asclepias syriaca), foxtail grass (Setaria glauca), and a sorrel (Rumex acetosella). The more complex upland areas were dominated by two species of grass, needlegrass (Aristida purpurascens) and Canada bluegrass (Poa compressa). Witch grass (Leptoloma cognatum) and panic grass (Panicum depauperatum) occurred in patches. The most common forbs included: blazing star (Liatris aspera), goldenrods (Solidago rigida and $S$. juncea), everlasting ( $A n$ tennaria neglecta), hawkweed (Hieracium longipilum), bush clovers (Lespedeza capitata and $L$. virginica), and sorrel (Rumex acetosella). Extensive patches of mosses and lichens occurred on the drier sites, often in association with Panicum spp.

There was little change in the species list of the flora during the 5-year period between the two studies cited above. Nor has the species complex changed in any obvious way between 1953 and the period when the major portion of the field work reported in this paper was done (1959-60). The field has remained for over 30 years in the grassforb stage of old field succession, but will probably revert eventually to oak-hickory forest, the 
natural vegetation on similar unplowed sites nearby. Evidence presented in this paper, however, shows that although the species presence list has had considerable stability, the percentage representation of grasses versus forbs in the vegetation biomass has changed quite markedly in the decade 1950-60.

\section{Methods}

\section{Measurement of standing crop}

The majority of the data on standing crops reported in this paper were obtained in 1951, 1959, and 1960 . In addition, some data were available from standing-crop determinations made during the years 1949,1952, 1953, 1954, and 1956 by various persons associated with the Laboratory of Vertebrate Biology, University of Michigan. In these latter years, the methods of clipping, handling, and weighing the vegetation were similar to those employed in the 1951 study. With the exception of 1949 , when a quadrat of $0.5 \mathrm{~m}^{2}$ was used, the quadrat size was $0.25 \mathrm{~m}^{2}$. Sampling was confined to a single date, or period, when the peak standing crop was expected, and the quadrats were placed non-randomly. The number of quadrats used in calculating the mean peak standing crop for a year varied from 7 to 20 .

In 1951 the standing crop of vegetation on the upland part of the Old Field was sampled with a series of clipped quadrats taken at weekly intervals from the middle of May to the end of September. Each quadrat was 0.5 meter on a side, and four quadrats were taken each week for 20 successive weeks. The standing plant material of each quadrat was clipped at the ground surface. After this had been cleared, the surface was carefully scraped to collect all fallen debris and undecomposed material from previous years. The total product of each sample was then sorted into two categories: (a) mulch, which included all gray, weathered stems and all plant debris that was not yet incorporated in the soil as humus; and (b) current vegetation, which included all green growth and recently produced dead material that showed no signs of weathering. The current vegetation was further sorted by species. Both mulch and current vegetation were stored in a dry room for several months, after which they were weighed on a pulp balance with a sensitivity of $0.002 \mathrm{~g}$.

During the growing seasons of 1959 and 1960 the standing crop of aboveground vegetation was sampled at intervals of 15 to 59 days. Because of the heterogeneity in the distribution of plant biomass on the field, a stratified-random sampling method was employed. Three classes (sampling "strata") of vegetation were recognized: (1) up- land grass-dominated, (2) upland bryoid-dominated, and (3) swale. The methods of computing the area occupied by each class and of locating the permanent sampling stations, together with procedure used for determining the optimum quadrat size, have been described (Wiegert 1962).

At each permanent sampling location a square $5 \mathrm{~m}$ on a side was laid out, with the permanent stake as its northwest corner. Each of the squaremeter areas in this permanent plot was given a number, proceeding from west to east, and from north to south. Before each set of samples was taken, one of these numbered square-meter areas was selected randomly for each permanent station and the clip quadrats for a day's sampling might proceed: station 1 , square 14 ; station 2 , square 5 , etc. A given location was used only once.

The quadrat frames were laid flat on the ground and all vegetation, both living and dead, was clipped and placed in plastic bags, along with all litter that could be scraped up. This material was later sorted into three categories: (1) green grass, (2) green forbs, and (3) dead material. Dead parts of single plants or leaves were separated from the living parts. The material was subsequently dried at $100^{\circ} \mathrm{C}$ for $36-48$ hours, and weighed on a balance sensitive to $0.01 \mathrm{~g}$.

Nested quadrats (the largest $0.25 \mathrm{~m}^{2}$ in area) were used for taking the first set of samples in 1959 (May 18). An analysis of these data (Wiegert 1962) gave the optimum quadrat sizes for sampling grasses $\left(0.05 \mathrm{~m}^{2}\right)$ and forbs $\left(0.20 \mathrm{~m}^{2}\right)$. The estimates of standing crops of grasses were of major interest, so all subsequent sampling in 1959 was done with a square quadrat of area $0.05 \mathrm{~m}^{2}$. In 1960 the sampling methods were improved slightly by the use of a circular quadrat to reduce bias caused by edge effect. In addition, two quadrat sizes were used. Grasses were sampled with a quadrat of $0.05 \mathrm{~m}^{2}$ and forbs were sampled with one of $0.20 \mathrm{~m}^{2}$. The two quadrats were laid down together, the smaller centered within the larger. After all vegetation had been removed from the inside of the smaller quadrat, the living forbs only were clipped from the remaining area enclosed within the larger quadrat. A mean and variance were calculated for each plant-material category (grass, forbs, dead) and for each vegetation class (upland-grass, upland-bryoid, and swale).

On May 18, 1959, the first sampling date of the season, the relative areas of the vegetation classes were: upland-grass 0.665 , upland bryoid 0.299 , and swale 0.036 . Thirty samples were taken, allocated as follows: upland-grass, 16; upland-bryoid, 8 ; swale, 6 . All subsequent collections in 1959 were made with 50 samples in each set, with the following apportionment: upland- 
grass, 28; upland-bryoid, 14 ; swale, 8. The 1959 data indicated that revision of the station allocations would increase the accuracy of the mean estimate. Accordingly, the 1960 allocation of the 50 permanent stations was modified to: uplandgrass, 36 ; upland-bryoid, 6; swale, 8.

The upland-grass and upland-bryoid classes together constitute the "upland types" and the swale class comprises the "depression types" of Evans and Dahl (1955). Although the swales occupy only a small part of the field, they are sharply differentiated, both floristically and physiographically, from the upland areas (Evans and Dahl 1955). The upland-grass and upland-bryoid classes differ primarily in the higher biomass of both green and dead vegetation found on the former.

In presenting the data a simple mean and variance for the swale class were calculated on the basis of the eight random samples. The means and variances from the upland-grass and upland-bryoid classes were combined to give a weighted mean standing crop plus an error term for the entire upland area of the field (Cochran, W. G., in Snedecor 1956, p. 511).

The standing crop of roots was measured on October 18, 1960, and again on May 20, 1961. On each of these dates 10 stations were randomly selected in the upland-grass area, three each in the upland-bryoid and swale classes. At each sampling point a circular quadrat $0.05 \mathrm{~m}^{2}$ in area was placed on the ground and all standing vegetation plus dead material was removed. The soil from the area inside the quadrat was then removed to a depth of approximately $25 \mathrm{~cm}$ and placed in a paper bag. The roots were later washed free of all soil, dried at $100^{\circ} \mathrm{C}$ for 48 hours, and weighed. The separation technique included an initial wash on fine window screen, combined with subsequent flotation of the dried material to rid it of larger stones and gravel. In this way loss of small rootlets was avoided. The calculation of mean and error terms followed the procedure outlined for the aboveground plant parts.

\section{Disappearance rate of dead material}

The rate at which dead material disappears from the field was estimated in two different ways. The first of these is referred to in this paper as the "paired-plots method." If the dead material is removed from a given area of a field and weighed $\left(W_{\mathrm{o}}\right)$ at a time $t_{\mathrm{o}}$, and if the dead material from a second area identical in size to the first is removed and weighed $\left(W_{1}\right)$ at time $t_{1}$, the instantaneous rate of disappearance of dead material from these plots can be calculated as :

$$
r=\frac{1 n\left(W_{0} / W_{1}\right)}{t_{1}-t_{0}}
$$

where $r=$ disappearance rate in $\mathrm{g}: \mathrm{g}:$ day and $\left(t_{1}-t_{0}\right)$ is in days.

Equation (1) requires that certain assumptions be met. First, the rates of disappearance from the two quadrats must be equal. Second, the biomass and the species composition of the dead material on the two quadrats must be identical. And, third, no additional material can be added to the dead material of the second quadrat during the interval $t_{1}-t_{0}$.

The following procedure was designed to minimize the error resulting from these assumptions. An area on the field, approximately $2 \mathrm{~m}$ on a side, was selected at random. Within this area two square quadrats, each $0.05 \mathrm{~m}^{2}$ in area, were arbitrarily located so that they shared one border and so that the amounts and species composition of the dead material in each were approximately the same. The living vegetation on each of the quadrats was removed by selective clipping. Next, one of the quadrats was selected at random and the dead material removed from it, dried, and weighed. After an interval the sampling area was revisited, the new growth in the second quadrat carefully removed, and the remaining dead material taken up, dried, and weighed.

The contiguous placement of the quadrats minimized the error due to possible differences in rate of disappearance between points on the field. It also made easier the task of enclosing areas approximately equal with respect to density and species composition of the dead material. This identity was, of course, not complete, and the error is unknown. But by setting up several of these "paired plots" and always selecting the first quadrat to be clipped by some random method, bias was avoided. The time interval between sampling periods was selected to avoid addition to the dead material from the mortality of new growth.

In 1959 paired plots were set up at six randomly chosen localities on the Old Field, five in the upland area and one in the swale area. The rate of disappearance was measured over the 55-day interval from July 14 to September 7. In 1960 a series of determinations was made over the entire growing season, and the number of paired plots was increased. Rates of disappearance were measured during the following periods: May 2June 21 ( 50 days) ; June 21-August 12 ( 52 days); August 12-October 1 (50 days); and October 1January 14 (105 days). At the beginning of each period paired plots were set up on 10 localities 
randomly selected within the upland area and on two localities randomly chosen from the swale area.

The rate of disappearance of dead material during the winter of 1959-60 was calculated differently. We assumed that all the green material present on the Old Field on November 21, 1959, died during the winter and that there was no growth and subsequent mortality during this time. An instantaneous rate of disappearance was then calculated from the difference between total vegetation per square meter on November 21, 1959, and dead material remaining per square meter on April 16, 1960, an interval of 147 days.

The second method used to measure disappearance rate of dead material was a variation of the standard litterbag technique. On May 18, 1960, plastic-screen mesh bags containing dead vegetation were placed on the ground at five localities chosen at random within the upland areas. Each 9- by 9-inch bag contained $10.0 \mathrm{~g}$ of dead material from one of four species of plants: Poa compressa, Aristida purpurascens, Lespedeza capitata, or Solidago rigida. At each locality 16 bags were used, four for each of the four species. The site was prepared by removing all vegetation, dead material, and humus. The bags were then placed next to each other on the exposed soil. A covering of chicken wire prevented displacement by wind or animal. The dead material used in the experiment was collected from the Old Field in the fall of 1959. It was unweathered and contained all aboveground parts of the representative plants.

At each location, one sample of each of the four species was picked up on the following dates: July 18, 1960; September 18, 1960; November 18, 1960; and May 20, 1961. These samples were cleaned of sand and of new growth that had pushed through the meshes of the bag. They were then dried at $100^{\circ} \mathrm{C}$ for 48 hours and weighed. In calculating the instantaneous rates of disappearance during a period, the rate was assumed to be the same for all four bags of a given species at the same location. Thus, the weights of the samples picked up on July 18,1959 , were used as the starting weights for the period July 18-September 18, etc.

\section{Caloric determinations}

All caloric values were determined from plant material collected from the Old Field. This material was dried for 48 hours at $100^{\circ} \mathrm{C}$, ground in a hand-operated coffee mill, reduced to powder with a mortar and pestle, formed into pellets, and stored for several days in a desiccator over a drying agent. ' The caloric content was measured with the bomb calorimeter and procedure described by Richman (1958). A Parr calorimeter thermome- ter was used in place of the Beckman thermometer employed by Richman.

\section{Results and Discussion}

\section{Standing crop of aboveground vegetation}

At the time the reserve was established (1928), the Old Field had been used as a pasture for a number of years. Succession has been extremely slow. The reasons for this are not fully known, but the poor quality of the soil plus the grazing by whitetail deer are probably important factors. There has been little intrusion of woody plants into the field and at the present time the overall aspect is still that of a grass-dominated area. In the period 1948-60 no significant changes in the species composition were observed. During these 12 years, however, a gradual change has occurred in the relative proportion of grasses in the standing crops.

Standing-crop measurements were compiled for the 12-year period. The values shown in Fig. 1 represent the grams per square meter of green vegetation plus dead material formed during the growing season of the given year; the magnitudes of the bars represent the means of all quadrats clipped during the period July 11-September 19. The sampling procedure varied from year to year and in some cases was not strictly random. Furthermore, because sampling was confined to the upland areas, the values are not representative of the field as a whole. Finally, the values given in Fig. 1 are based on air-dry weights. Because the data for 1959-60 were obtained from ovendry material and were based on samples of the total dead material on the field instead of the "current year"

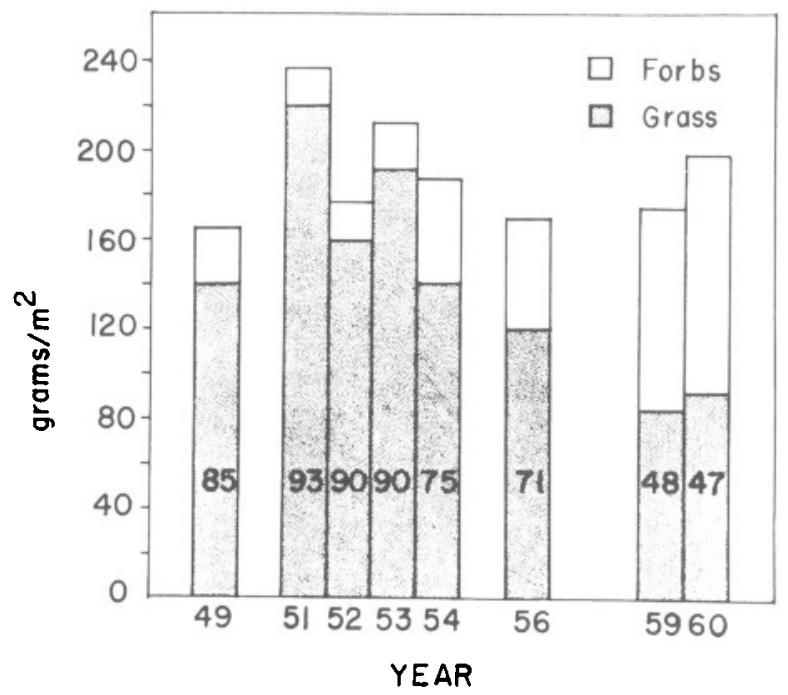

Fic. 1. Peak standing crops of vegetation on uplandgrass areas of Evans Old Field during the period 194960 . Stippled areas represent grasses, clear areas represent forbs. Percentages are given for grasses. 
dead matter, they have been corrected for inclusion in the graph by assuming that one-half of the total organic matter on the field consisted of green material plus dead material from the current growing season; $10 \%$ of the ovendry weights has been added to correct to air-dry weight.

Despite the limitations of these data, they show clearly that the total standing crop during late summer has remained relatively constant from year to year. The extremes are noted in 1949 and $1951\left(165.0 \mathrm{~g} / \mathrm{m}^{2}\right.$ vs. $\left.237.9 \mathrm{~g} / \mathrm{m}^{2}\right)$. There is no obvious trend with time in the changes in standing crop. The relative representation of grasses in the total standing crop has, however, changed considerably. In the early years grasses were a major component, accounting for more than $80 \%$ of the total standing crop. By 1960 the percentage had decreased to less than $50 \%$. This increase in forb biomass has not been accompanied by any great change in the species involved.

There was also a difference in the seasonal distribution of grass-versus-forb biomass between the years 1951 and 1960 . In 1951 the percentage of grasses in the total standing crop remained between 90 and 100 throughout the growing season. In 1960, however, the standing crop in mid-April contained slightly more than $70 \%$ grass, decreasing to less than $50 \%$ in midsummer and to less than $30 \%$ by late fall. The increase in importance of forb species on the field has emphasized their slower rate of growth and later maturity date, as compared to the grass species.

The data presented thus far indicate that the succession on the field is proceeding slowly in the direction of dominance by species of perennial forbs. It appears, however, that the upland area of the field has achieved a considerable degree of stability with respect to the total biomass of vegetation per unit area. Judged solely on the basis of data from 1959 and 1960 the situation is probably similar on the swales. These indications of stability in the Old Field vegetation become more marked when the standing crop and production data from 1959 and 1960 are considered.

The most obvious division of the vegetation of the Old Field is that of upland areas versus the swales (Table I). These two areas are separated by physiographic factors as well as by species differences. Equally as striking are the differences in magnitude and seasonal distribution of the biomass of their various plant components. Although the field was divided into three classes for purposes of increasing the sampling efficiency, there was little vegetational difference between the uplandgrass and the upland-bryoid classes except in the magnitude of the standing crop. The data from the upland and bryoid classes have therefore been
TABLE I. Standing crops of green grass, green forbs, total green vegetation, and dead material on Evans Old Field, 1959 and 1960 -expressed in grams per square meter ovendry weight ${ }^{1}$

\begin{tabular}{|c|c|c|c|c|c|c|c|c|}
\hline \multirow[b]{2}{*}{ Date } & \multicolumn{4}{|c|}{ Upland } & \multicolumn{4}{|c|}{ Swale } \\
\hline & Grass & Forbs & Total & Dead & Grass & Forbs & Total & Dead \\
\hline 1959 & & & & & & & & \\
\hline $5 / 18 \ldots \ldots \ldots$ & 12 & 16 & 28 & 149 & 82 & 8 & 90 & 264 \\
\hline $6 / 3 \ldots \ldots \ldots$ & 26 & 37 & 63 & 138 & 105 & 26 & 131 & 230 \\
\hline $6 / 18 \ldots \ldots$ & 37 & 43 & 80 & 150 & 130 & 54 & 184 & 285 \\
\hline $7 / 4 \ldots \ldots$ & 40 & 55 & 95 & 178 & 99 & 32 & 131 & 366 \\
\hline $7 / 21 \ldots \ldots \ldots$ & 45 & 50 & 95 & 180 & 135 & 94 & 229 & 510 \\
\hline $8 / 5 \ldots \ldots \ldots$ & 45 & 70 & 115 & 174 & 143 & 25 & 168 & 376 \\
\hline $8 / 22 \ldots$ & 56 & 58 & 114 & 172 & 168 & 42 & 210 & 411 \\
\hline $9 / 7 \ldots \ldots$ & 49 & 72 & 121 & 187 & 115 & 31 & 146 & 398 \\
\hline $9 / 23 \ldots$ & 50 & 60 & 110 & 148 & 176 & 14 & 190 & 369 \\
\hline $11 / 21 \ldots$ & 5 & 10 & 15 & 203 & 86 & 13 & 99 & 456 \\
\hline 1960 & & & & & & & & \\
\hline $4 / 16 \ldots$ & 4 & 2 & 6 & 179 & 29 & 1 & 30 & 417 \\
\hline $5 / 16 \ldots \ldots \ldots$ & 11 & 13 & 24 & 168 & 61 & 2 & 63 & 357 \\
\hline $6 / 4 \ldots \ldots$ & 26 & 37 & 63 & 158 & 131 & 18 & 149 & 281 \\
\hline $6 / 27$ & 48 & 63 & 111 & 143 & 169 & 28 & 197 & 294 \\
\hline $7 / 18 \ldots \ldots$ & 62 & 66 & 128 & 178 & 157 & 41 & 198 & 475 \\
\hline $8 / 8 \ldots \ldots$ & 53 & 80 & 133 & 170 & 155 & 62 & 217 & 469 \\
\hline $9 / 8 \ldots \ldots \ldots$ & 50 & 77 & 127 & 160 & 139 & 39 & 178 & 417 \\
\hline $10 / 18 \ldots \ldots$ & 3 & 9 & 12 & 256 & 35 & 1 & 36 & 604 \\
\hline
\end{tabular}

${ }^{1}$ All values given to the nearest gram.

combined and the name "upland" given to the resulting area of the field (Table I).

Seasonal changes in the biomass of the various components of the vegetation present some interesting differences (Table I, Fig. 2). The

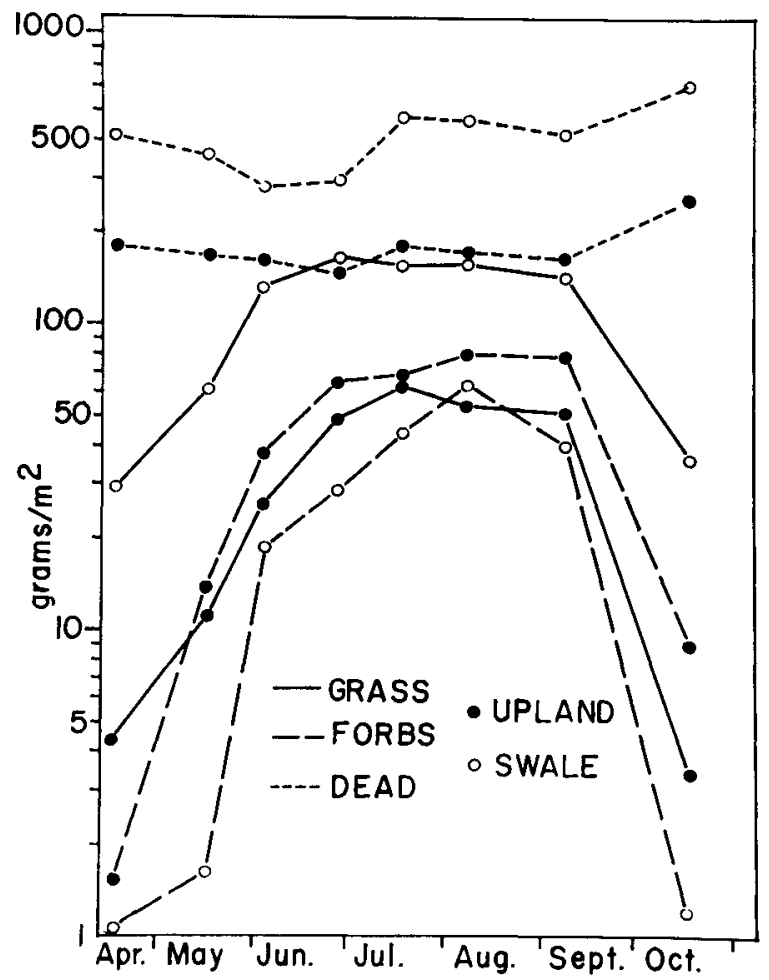

FIG. 2. Standing crops (ovendry weights) of living and dead vegetation on the Evans Old Field during 1960. 
changes in standing crop, were remarkably similar in 1959 and 1960, and the following remarks apply equally to the two years. The standing crop of dead material varies little throughout the year. There is a rise in late fall, corresponding to the maturation and death of remaining green plant material with the advent of frosts. The lowest point occurred in late May and early June. There was somewhat more than twice as much dead material per square meter in the swales as on the upland area.

The highest biomass of green grass was found on the swale, where values exceeding $100 \mathrm{~g} / \mathrm{m}^{2}$ occurred over most of the growing season. The seasonal fluctuation (in per cent) of the standing crop of green grass on the swales was less than that of the grass on the upland and also lower than that of the forbs on either upland or swale. This uniformity was most pronounced in 1959, where the seasonal fluctuation in the standing crop of swale biomass approximated that of dead material. Swale grass showed a greater decrease in the autumn of 1960 than in the autumn of 1959 , but even so, more than $30 \mathrm{~g} / \mathrm{m}^{2}$ were present on October 18, 1960.

In contrast to the high biomass of green grass on the swales, swale forbs usually showed a lower biomass per square meter than either the grass or forb categories of the upland areas. The latter two categories were quite similar with respect to magnitude and seasonal distribution of the standing crop; grasses were slightly higher early and lower than forbs later in the season. All three (swale grass, upland forbs, and upland grass) showed about the same amplitude in the seasonal change in standing crop, and all three were maintained at very low levels during the winter. So far as standing crops are concerned, the swales differ from the upland areas chiefly in the higher total biomass of dead material and green grass on the former, plus a lesser amplitude in the percentage change occurring during the growing season in the standing crop of green grass on the swales.

Ninety-five per cent confidence limits of the mean were calculated for all the values given in Table I. These were expressed as percentages of the mean standing crop and are summarized in Table II as a range and average value for each vegetation category, from each area of the field, in each year. The values for total green material will be referred to in a later section of this paper. The data for dead material were the least variable; those for forbs were the most variable. The increase in quadrat size for sampling forbs from $0.05 \mathrm{~m}^{2}$ in 1959 to $0.20 \mathrm{~m}^{2}$ in 1960 resulted in a considerable decrease in the variance for the up-
TABLE II. Range of $95 \%$ confidence limits of the means of standing crops for all four vegetation categories on the upland and swale areas of the Evans Old Field, 1959-60 [All values as percentage of mean standing crop; average values for the season in parentheses]

\begin{tabular}{l|c|c|c|c}
\hline \multirow{4}{*}{$\begin{array}{l}\text { Vegetation } \\
\text { category }\end{array}$} & \multicolumn{2}{|c|}{ Upland } & \multicolumn{2}{c}{ Swale } \\
\cline { 2 - 3 } Total green & 1959 & 1960 & 1959 & 1960 \\
& $30.1-16.4$ & $33.3-14.9$ & $73.7-8.7$ & $49.7-18.1$ \\
& $(23.0)$ & $(19.3)$ & $(27.1)$ & $(28.6)$ \\
Grass & & & & \\
& $34.6-16.8$ & $42.4-16.7$ & $41.5-20.9$ & $52.4-21.5$ \\
Forbs & $(22.1)$ & $(22.0)$ & $(29.7)$ & $(32.2)$ \\
& & & & \\
Dead & $49.4-30.1$ & $46.0-19.7$ & $137.2-70.4$ & $141.7-52.3$ \\
& $(38.3)$ & $(27.5)$ & $(97.6)$ & $(97.8)$ \\
& $19.8-12.9$ & $19.6-12.3$ & $36.1-11.1$ & $27.3-7.8$ \\
& $(16.2)$ & $(16.4)$ & $(17.8)$ & $(16.7)$ \\
\hline
\end{tabular}

land samples. The wide confidence limits of the mean for the swale forbs (often exceeding $100 \%$ ) were the least acceptable, reflecting both the highly clumped distribution of a few large plants (especially of milkweed, Asclepias syricaca) and the small number of samples (eight) apportioned to this class.

\section{Standing crop of roots}

On October 18, 1960, the mean standing crop of roots was $685 \mathrm{~g} / \mathrm{m}^{2}$ on the upland area of the field and $1,018 \mathrm{~g} / \mathrm{m}^{2}$ in the swales (Table III).

TABLE III. Standing crop of roots (grams per square meter) on upland and swale areas of Evans Old Field and $95 \%$ confidence limits of mean-1960-61

\begin{tabular}{|c|c|c|c|c|}
\hline & \multicolumn{2}{|c|}{ Upland } & \multicolumn{2}{|c|}{ Swale } \\
\hline Date & Mean & $\begin{array}{l}95 \% \text { limits } \\
\text { of mean }\end{array}$ & Mean & $\begin{array}{l}95 \% \text { limits } \\
\text { of mean }\end{array}$ \\
\hline $\begin{array}{r}10 / 18 / 60 \\
5 / 20 / 61\end{array}$ & $\begin{array}{l}685 \\
542\end{array}$ & $\begin{array}{r}137 \\
88\end{array}$ & $\begin{array}{r}1018 \\
660\end{array}$ & $\begin{array}{l}407 \\
685\end{array}$ \\
\hline
\end{tabular}

By May 20, 1961, the biomass of roots had decreased to $542 \mathrm{~g} / \mathrm{m}^{2}$ in the upland and $660 \mathrm{~g} / \mathrm{m}^{2}$ in the swales. The $95 \%$ confidence limits of these mean estimates were close to $20 \%$ for the upland data, but they were much higher (40 to $104 \%$ ) for the swale data because of the small number of samples taken. These values for root biomass are undoubtedly underestimates. Forbs such as Liatris possess a deeply penetrating taproot (Weaver 1958a) and their root systems are not adequately sampled by $25-\mathrm{cm}$ deep cores. Soil pits dug on the field in the early years of the present study, however, showed that almost all of the shallow, branching roots, particularly of the grasses, were restricted to the soil above the old plow line, which averages less than $25 \mathrm{~cm}$ in depth (Evans and Dahl 1955). Values given by Weaver (1958b) 


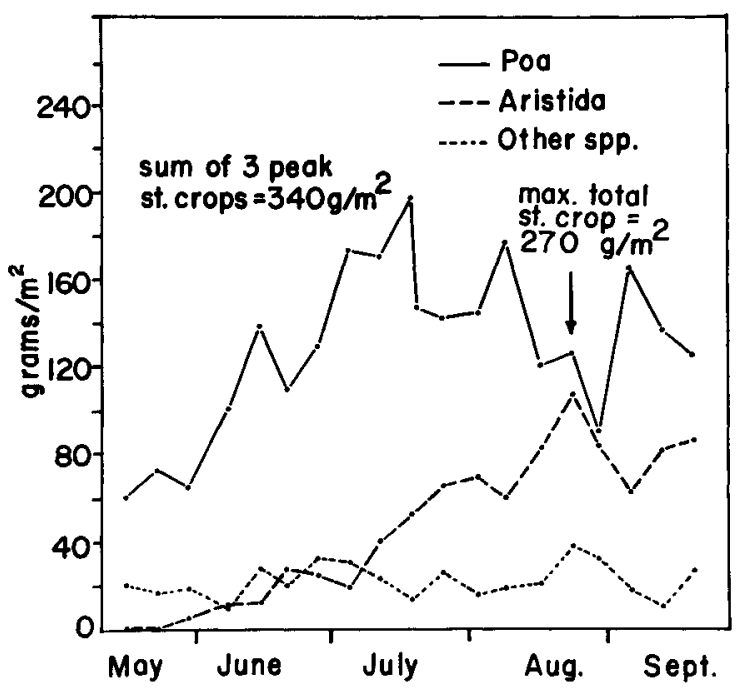

FIG. 3. Standing crops of Canada bluegrass (Poa compressa), needlegrass (Aristida purpurascens), and all other vegetation on Evans Old Field during 1951. Values represent ovendry weights of green material plus dead material produced during 1951.

indicate that even for the large prairie grasses, from $55 \%$ to $79 \%$ of the roots occur in the top 6 inches $(15 \mathrm{~cm})$. The smaller bluegrasses (Poa compressa and Poa pratensis) have even shallower root systems. It is probable that the root biomass values for the species sampled are not more than $50 \%$ in error.

\section{Peak standing crops}

In a heterogeneous area such as the Old Field, the peak standing crops of all species do not occur simultaneously. The samples collected on the upland in 1951 were separated by species and the data nicely illustrate the error that could arise in the estimation of production from standing crop alone (Fig. 3).

Because the two grasses, Poa compressa and Aristida purpurascens, accounted for almost 90\% of the biomass, the remaining species of plants have been lumped into an "other" category. Fig. 3 shows that Poa compressa increased in biomass more rapidly than Aristida and reached a peak on July 18. The peak standing crops of Aristida and the "other" vegetation occurred on August 23 ; on this date the peak in total standing vegetation also was reached. By the increment method, assuming zero standing crop at the beginning of the growing season, the total production would be estimated as $270 \mathrm{~g} / \mathrm{m}^{2}$. The summation of the peak standing crops by species, however, gives a value in excess of $340 \mathrm{~g} / \mathrm{m}^{2}$. Thus, even when the possibility of mortality and growth between sampling periods is ignored, the production estimate is
TABLE IV. Disappearance rate of dead material measured with the paired-plots method, Evans Old Field, $1959-60$

\begin{tabular}{|c|c|c|c|c|c|}
\hline \multirow[b]{2}{*}{ Interval } & \multirow[b]{2}{*}{ Days } & \multicolumn{2}{|r|}{ Upland } & \multicolumn{2}{|c|}{ Swale } \\
\hline & & $\begin{array}{c}\text { No. of pairs } \\
\text { of plots }\end{array}$ & $\begin{array}{c}\text { Instantaneous } \\
\text { rate (mg/g per } \\
\text { day) }\end{array}$ & $\begin{array}{c}\text { No. of pairs } \\
\text { of plots }\end{array}$ & $\begin{array}{l}\text { Instantaneous } \\
\text { rate (mg/g per } \\
\text { day) }\end{array}$ \\
\hline 1959 & & & & & \\
\hline $7 / 14-9 / 7$ & 55 & 5 & 8.4 & 1 & 12.1 \\
\hline 1958-60 & & & & & \\
\hline $11 / 21-4 / 16$ & 147 & * & 1.3 & - & - \\
\hline 1960 & & & & & \\
\hline $5 / 2-6 / 21$ & 50 & 10 & 8.1 & 2 & 13.6 \\
\hline $6 / 21-8 / 12$ & 52 & 10 & 7.9 & 1 & 9.3 \\
\hline $8 / 12-10 / 1$ & 50 & 10 & 6.0 & 2 & 12.9 \\
\hline 1960-61 & & & & & \\
\hline $10 / 1-1 / 14$ & 105 & 10 & 4.4 & 1 & 1.8 \\
\hline
\end{tabular}

*No paired plots. Value calculated from standing erops of dead material on the wo dates.

increased $22 \%$ by considering the peak standing crops of each species separately, as opposed to a value for the peak standing crop of the vegetation as a whole.

\section{The disappearance of dead material}

Rates of disappearance of dead material on the Old Field were determined by the paired-plots method for different times of the year (Table IV). The instantaneous rate on the upland area varied from $8.4 \mathrm{mg} / \mathrm{g}$ per day to $1.3 \mathrm{mg} / \mathrm{g}$ per day. The rate was highest during the early part of the growing season, decreased as the season progressed, and was lowest during the winter. The rate on the swales varied from $13.6 \mathrm{mg} / \mathrm{g}$ per day to $1.8 \mathrm{mg} / \mathrm{g}$ per day, and with the exception of the period August 12-October 1, 1960, the change in rate with season was the same as on the upland area. The value obtained from the pilot experiment of 1959 was similar to the rates measured in the comparable period of 1960 (Table IV). The rate for the winter of 1959-60 was not measured by the paired-plots method but was computed from the decreases in the total standing crop of dead material (see Methods section).

Although the rates measured on the swale areas varied over a wider range than did those measured on the upland area, and the number of plots on the swales was low, the results in Table IV indicate that the rate of disappearance on the swales was greater than that on the upland. This condition is to be expected because of the more moist conditions prevalent in the swales.

The second method of measuring the disappearance rate of dead material, that of using mesh bags, was designed to answer two questions that cannot be evaluated using the paired-plots method: (1) does the rate of disappearance vary with position 
TABLE V. Instantaneous rates of disappearance, by species, of dead material from mesh bags on Evans Old Field, 1960-61-all values in $\mathrm{mg} / \mathrm{g}$ per day

\begin{tabular}{c|c|c|c|c}
\hline \hline Interval & $\begin{array}{c}\text { P. com- } \\
\text { pressa }\end{array}$ & $\begin{array}{c}\text { A. pur- } \\
\text { purascens }\end{array}$ & $\begin{array}{c}S . \\
\text { rigida }\end{array}$ & $\begin{array}{c}L . \\
\text { capitata }\end{array}$ \\
\hline $5 / 18-7 / 18 \ldots \ldots$ & 4.1 & 1.0 & 4.6 & 0.2 \\
$7 / 18-9 / 18 \ldots \ldots$ & 2.0 & 2.7 & 3.6 & 1.5 \\
$9 / 18-11 / 18 \ldots \ldots$ & 1.6 & 2.0 & 2.0 & 1.1 \\
$11 / 18-5 / 20 \ldots \ldots$ & 0.4 & 0.1 & 0.3 & 0.3 \\
\hline
\end{tabular}

TABLE VI. Instantaneous rates of disappearance, by station, of dead material from mesh bags on Evans Old Field, 1950-61-all values in $\mathrm{mg} / \mathrm{g}$ per day

\begin{tabular}{|c|c|c|c|c|c|c|}
\hline \multirow[b]{2}{*}{ Interval } & \multicolumn{5}{|c|}{ Station } & \multirow{2}{*}{$\begin{array}{l}\text { Rates calculated } \\
\text { from sum of all } \\
\text { station weights }\end{array}$} \\
\hline & 1 & 2 & 3 & 4 & 5 & \\
\hline $\begin{array}{c}5 / 18-7 / 18 \\
7 / 18-9 / 18 \\
9 / 18-11 / 18 \\
11 / 18-5 / 20\end{array}$ & $\begin{array}{l}2.0 \\
3.2 \\
1.0 \\
0.3\end{array}$ & $\begin{array}{l}2.7 \\
1.1 \\
2.0 \\
0.3\end{array}$ & $\begin{array}{l}2.6 \\
2.0 \\
1.6 \\
0.3\end{array}$ & $\begin{array}{l}2.4 \\
2.5 \\
1.9 \\
0.1\end{array}$ & $\begin{array}{l}1.7 \\
2.7 \\
2.1 \\
0.3\end{array}$ & $\begin{array}{l}2.4 \\
2.3 \\
1.7 \\
0.3\end{array}$ \\
\hline
\end{tabular}

on the upland, and (2) does the rate of disappearance differ with species? Variance in the rate of disappearance with time of year was also tested. The relevant data are given in Tables $\mathrm{V}$ and VI. The null hypotheses tested were:

$\mathrm{H}_{0} 1$. The species rates of disappearance do not differ with species.

$\mathrm{H}_{0}$ 2. The species rates of disappearance do not differ with time of year.

$\mathrm{H}_{0} 3$. The station rates of disappearance do not differ with stations.

$\mathrm{H}_{0} 4$. The station rates of disappearance do not differ with time of year.

The data of Table $\mathrm{V}$ were used to test null hypotheses (1) and (2); the data of Table VI were used for (3) and (4). In all four cases the nonparametric Friedman two-way analysis of variance was employed (Siegel 1956).

The following probabilities were obtained:

$$
\begin{array}{lr}
\mathrm{H}_{0} 1 . & 0.16>\mathrm{p}>0.14 \\
\mathrm{H}_{0} 2 . & \mathrm{p}=0.09 \\
\mathrm{H}_{0} 3 . & 0.95>\mathrm{p}>0.90 \\
\mathrm{H}_{0} 4 . & 0.01>\mathrm{p}>0.001
\end{array}
$$

Null hypothesis (3) is accepted with a high level of confidence, and $\mathrm{H}_{0}(4)$ is rejected at a high significance level. Thus, we conclude that rates of disappearance did not differ between stations, but that they did differ with time of year. These two results were expected on the basis of a similarity between different parts of the upland area of the field (no difference in disappearance rate between stations), and on the basis of a climate with marked seasonal fluctuations in tem- perature and rainfall (station disappearance rates differ with time of year). Null hypotheses (1) and (2) have associated probabilities in a borderline zone $0.05<\mathrm{p}<0.20$ which precludes unqualified acceptance or rejection. Null hypothesis (1) approaches the level of acceptance and one feels intuitively that $\mathrm{H}_{0}(2)$ should be rejected because of the highly significant difference of station rates with time of year. The reason for the weakness of the conclusions from the statistical tests is apparent from Table V. Except for the low initial rates of disappearance for Aristida and Lespedeza, the species do not seem to differ greatly in rate of disappearance, and their rates decrease consistently with time of year, essentially like the station rates. These low initial rates of disappearance for Aristida and Lespedeza indicate a difference in the speed with which they begin to decompose, as compared with the other two species. This in turn implies that the change in disappearance rate with time of year might be complicated by a concurrent change in rate with time as measured from the start of the experiment.

Because the disappearance rates of material in mesh bags did not differ with station, the weights of all stations were summed for each sampling date, and instantaneous rates computed from these totals (Table VI). These rates are substantiaily lower than those obtained with weathered dead material in place on the field (Table IV). Even after 6 months of previous exposure to the weather, the rate measured with litterbags $(0.3 \mathrm{mg} / \mathrm{g}$ per day beween $11 / 19-5 / 20,1960-61$ ) was less than one-fourth of the $1.3 \mathrm{mg} / \mathrm{g}$ per day obtained from standing-crop data on the Old Field during the period 11/21-4/16, 1959-60.

Low rates were expected for the litterbag studies. First, a cohort of unweathered material would be unlikely to disappear at as great a rate as the naturally stratified dead layer on the field. Secondly, the litterbags greatly restrict the entry of larger invertebrates, scavengers, and decomposers that could be important consumers. Finally, by removing the vegetation to expose the soil surface we may have decreased the suitability of the microenvironment as a habitat for decomposer organisms.

Even the paired-plots method results in some disturbance of the system. Removal of the living vegetation on the decay plots could have altered the microclimate of the plot in the direction of lower relative humidity, increased solar radiation falling on the soil surface, a greater air movement, and a changed soil moisture.

Since these changes would result in a hotter. drier environment for the scavenger and decomposer populations, a reasonable assumption is that 
the decomposition rate would be lowered. Thus, to the extent that the above alterations in the microenvironment are produced, the values obtained from the paired-plots method underestimate the true disappearance rate.

On the upland part of the Old Field green vegetation is sparse and the larger forbs are widely scattered. They neither shade the ground nor impede air movement at the soil surface. Thus, the removal of the green vegetation hardly alters the appearance of the small plot, and discrepancies due to microenvironment changes appear negligible. A greater change could be expected on the swales, where removal of the heavier grass cover exposes the dead material more than that on adjacent, undisturbed areas. Comparison of plots artificially covered with cloth or plastic with uncovered controls would prove interesting.

Although continued testing may uncover further limitations of the method, the rates of disappearance measured with paired-plots appear to approximate the natural condition better than do rates of disappearance measured with litterbags. In all subsequent computations in this paper, rates derived from the values of Table IV are used.

\section{Caloric values of the vegetation}

The values of all caloric determinations, the mean for each vegetation category, and the standard deviations are given in Table VII. The over-

TABLE VII. Caloric values (Gcal/gm) of vegetationEvans Old Field

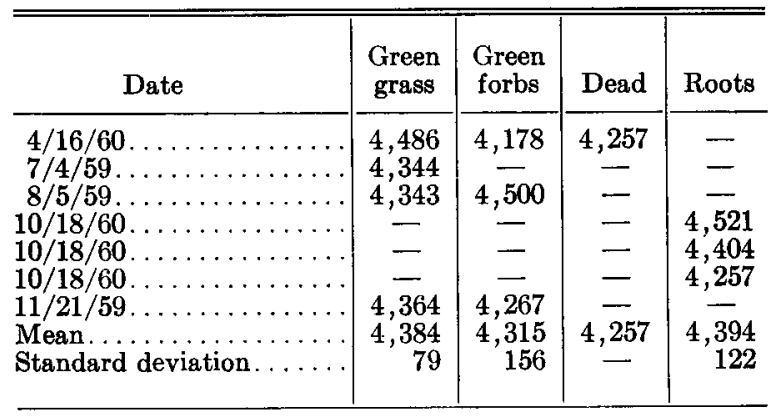

all range in caloric value for grasses differed little from that for forbs. Because there seemed to be no seasonal changes in the caloric value of either grasses or forbs, only a single determination was made on dead material. That value was found to be within the range exhibited by green forbs. The values in Table VII fall within the range for the caloric value of old field vegetation published by Golley (1961). In all subsequent calculations of the production of aboveground vegetation, one gram (dry weight) of production is assumed to contain 4,350 calories (mean of green grass and green forbs, Table VII). One gram of root biomass is assumed to contain 4,394 calories.

\section{Growth of aboveground vegetation (shoot growth)}

Change in the standing crop of green material during a given time interval comes as a result of two processes, growth and mortality. In terms of biomass of vegetation, the change in the standing crop is equal to growth minus mortality. Total growth in any interval is therefore equal to the sum of the change in the standing crop plus the mortality.

It is not possible to measure mortality directly, but the change in the standing crop of dead material during an interval is equal to the difference between the material added (mortality) and the material disappearing. Mortality is therefore equal to the sum of the amount disappearing plus the change in standing crop of dead material.

For a given interval a knowledge of the values of six different parameters will suffice to determine the growth of the aboveground vegetation exclusive of that consumed by herbivores. Standing crop data are expressed in grams per square meter; instantaneous rates in milligrams per gram per day.

Let :

$\boldsymbol{t}_{\boldsymbol{i}}=$ a time interval (in days)

$a_{i-1}=$ standing crop dead material at start

$a_{i}=$ standing crop dead material at end

$b_{i-1}=$ standing crop green material at start

$b_{i}=$ standing crop green material at end

$r_{i}=$ instantaneous daily rate of disappearance of dead material during interval

Let $x_{i}=$ amount of dead material disappearing during an interval:

$$
x_{i}=\left(a_{i}+a_{i-1}\right) / 2 \cdot r_{i} t_{i}
$$

The changes in standing crops of green and dead materials, respectively are :

$$
\begin{aligned}
& \Delta b_{i}=b_{i}-b_{i-1} \\
& \text { and } \\
& \Delta a_{i}=a_{i}-a_{i-1}
\end{aligned}
$$

Since $\Delta a_{i}$ is the change in dead standing crop during the interval, $\left(x_{i}+\Delta a_{i}\right)$ is the amount of material added to the dead standing crop during the interval, i.e., the mortality of green material (symbolized here by $d_{i}$ ).

$$
d_{i}=x_{i}+\Delta a_{i}
$$

Equation (5) must be $\supseteq 0$; negative values indicate an error in one or more of the measured parameters. 
The growth during a given interval $\left(t_{i}\right)$ is then given by:

$$
y_{i}=\Delta b_{i}+d_{i}
$$

where $y_{i}$ is measured in grams per unit area.

Equations (2) through (6) were used to calculate the disappearance, mortality, and growth of the vegetation during each sampling interval in 1959 and 1960 (Table VIII). The instantaneous rates of disappearance of dead material for the given intervals were calculated by appropriate weighting of the values in Table IV.

Because the sampling program did not extend over two calendar years, the 1960 data were used to estimate growth in the spring of 1959, and 1959 values were used to estimate late fall production in 1960. These estimated values are indicated by appropriate superscripts in Table VIII. In two instances in 1959 negative values for equation (5) were obtained and so the computations were made as of the mean values between sampling in- tervals. These latter dates and computed values are in parentheses in Table VIII.

Considerable green material is present on the swales throughout the winter months and some growth probably occurs during this time. Presumably this growth is a minor factor because of the subfreezing temperatures. Nevertheless, the values for swale net production given in Table VIII must be regarded as minimum estimates.

All three of the parameters-disappearance, mortality, and growth-vary in magnitude with time of year. Differences are also apparent between upland versus swale. But there is little difference between the two years, 1959 and 1960 . The sum of the growth column for the swale in 1959 (943 $\mathrm{g} / \mathrm{m}^{2}$ ) is approximately three times the growth on the upland in 1959 . The $1,064 \mathrm{~g} / \mathrm{m}^{2}$ produced on the swale in 1960 is similar to the swale value for 1959 and is also approximately three times the growth made on the upland in 1960 .

One of the major criticisms of the practice of

TABLE VIII. Disappearance, mortality, and growth (exclusive of herbivore consumption) of aboveground vegetation on Evans Old Field 1959-60 (Calculations based on means of two consecutive sampling dates are enclosed in parenthesis. Question marks indicate periods for which data were lacking. Vegetation data in grams per square meter.)

\begin{tabular}{|c|c|c|c|c|c|c|c|}
\hline \multirow[b]{2}{*}{ Date } & \multirow[b]{2}{*}{$\begin{array}{c}\text { Interval } \\
t_{i}\end{array}$} & \multicolumn{3}{|c|}{ Upland } & \multicolumn{3}{|c|}{ Swale } \\
\hline & & $\begin{array}{l}\text { Disappearance } \\
x_{i}\end{array}$ & $\begin{array}{l}\text { Mortality } \\
\quad d_{i}\end{array}$ & $\begin{array}{c}\text { Growth } \\
y_{i}\end{array}$ & $\begin{array}{c}\text { Disappearance } \\
x_{i}\end{array}$ & $\begin{array}{c}\text { Mortality } \\
d_{i}\end{array}$ & $\begin{array}{c}\text { Growth } \\
y_{i}\end{array}$ \\
\hline 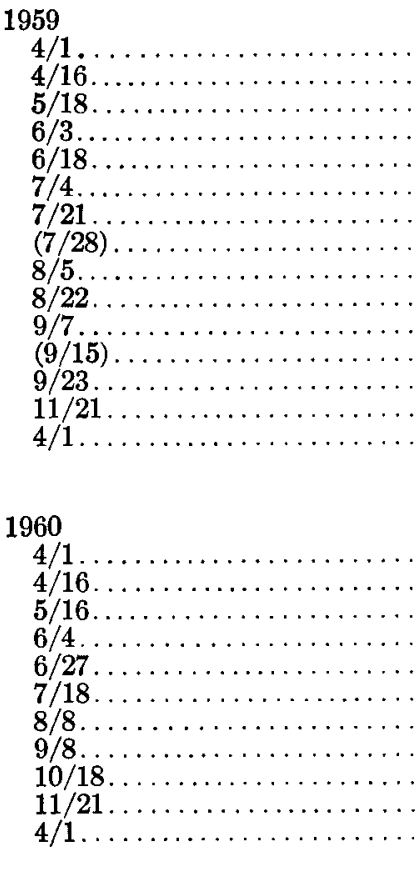 & $\begin{array}{r}15 \\
32 \\
16 \\
15 \\
16 \\
17 \\
7 \\
8 \\
17 \\
16 \\
8 \\
8 \\
59 \\
131 \\
365 \\
\\
15 \\
30 \\
19 \\
23 \\
21 \\
21 \\
31 \\
40 \\
34 \\
131 \\
365\end{array}$ & $\begin{array}{c}2 . \overline{3^{\mathrm{b}}} \\
45.2^{\circ} \\
19.1 \\
17.5 \\
20.8 \\
24.0 \\
21.0 \\
20.0 \\
(16.3) \\
67.0 \\
21.7\end{array}$ & $\begin{array}{c}\overline{0.0} \\
33.9^{\circ} \\
8.2 \\
29.6 \\
48.8 \\
25.3 \\
15.8 \\
17.6 \\
(12.0) \\
\\
(102.0) \\
15.0 \\
\\
\\
- \\
0.0 \\
31.9 \\
14.7 \\
13.5 \\
61.7 \\
20.5 \\
22.3 \\
139.7 \\
12.0 \\
0.0\end{array}$ & $\begin{array}{c}\overline{5.70} \\
53.5^{\circ} \\
43.4 \\
45.8 \\
64.4 \\
25.0 \\
35.5 \\
17.3 \\
\\
(13.4) \\
\\
1.3 \\
0.0 \\
305.3 \\
\\
\\
5.7 \\
50.2 \\
53.7 \\
61.3 \\
79.1 \\
25.1 \\
16.6 \\
27.6 \\
0.7^{\mathrm{a}} \\
0.0 \\
320.0\end{array}$ & $\begin{array}{c}- \\
? \\
168.4^{\circ} \\
53.7 \\
52.5 \\
52.6 \\
\\
(63.9) \\
\\
(114.6) \\
83.6 \\
79.2 \\
75.5 \\
? \\
\\
\\
\\
? \\
157.8 \\
82.4 \\
85.8 \\
75.1 \\
92.1 \\
170.0 \\
167.4 \\
43.5^{\mathrm{a}} \\
?\end{array}$ & $\begin{array}{c}- \\
? \\
104.7 \\
19.4 \\
107.7 \\
133.4 \\
\\
(141.2) \\
(83.1) \\
96.8 \\
50.4 \\
162.1 \\
? \\
\\
\\
7 \\
? \\
98.2 \\
6.0 \\
98.8 \\
256.5 \\
85.1 \\
118.6 \\
354.8 \\
? \\
?\end{array}$ & $\begin{array}{c}\bar{?} \\
140.5^{\circ} \\
60.5 \\
160.1 \\
80.2 \\
\\
(209.3) \\
(94.4) \\
33.0 \\
94.8 \\
70.3 \\
? \\
943.1 \\
\\
\\
? \\
131.6 \\
91.9 \\
147.5 \\
256.0 \\
104.0 \\
79.3 \\
213.3 \\
40.5 \\
? \\
1,064.1\end{array}$ \\
\hline
\end{tabular}


equating total annual growth with the annual change in producer biomass is that mortality occurring during the sampling interval will not be measured. Thus, we find that the annual growth estimates in Table VIII are greater than the peak standing crops given in Table I. On the upland the ratios of annual growth to peak standing crop of green material are 2.5 to 1 (1959) and 2.4 to 1 (1960). Those on the swale are 4.5 to 1 (1959) and 4.9 to 1 (1960). Thus, on the upland, true growth is some 2.5 times apparent growth, and on the swales it is almost five times apparent growth. Because grass is more or less constantly growing and dying throughout the season, the error introduced by equating annual growth with peak standing crop would have been greatest on the swales, where grass predominates in the green standing crop.

Ovington, Heitkamp, and Lawrence (1963) reported on the annual growth of prairie vegetation in central Minnesota. They regarded their published figures as underestimates, because they were based simply on the annual change in biomass of the producer organisms. Peak green standing crop on the prairie was $96 \mathrm{~g} / \mathrm{m}^{2} \mathrm{com}$ pared to $133 \mathrm{~g} / \mathrm{m}^{2}$ for the upland part of the Old Field in 1960. Peak standing crops of roots and stems were : prairie, $670 \mathrm{~g} / \mathrm{m}^{2}$; upland Old Field $1960,685 \mathrm{~g} / \mathrm{m}^{2}$. Ovington et al. estimated that the Minnesota prairie produced $93 \mathrm{~g}$ of plant biomass per square meter, compared to the $320 \mathrm{~g} / \mathrm{m}^{2}$ produced on the Old Field studied by us. The two areas may not be directly comparable. Yet both the growth form and standing crops of the vegetative components are similar enough that the great difference in annual growth is probably not real. If corrected for the mortality missed between sampling periods, and for the possible differences in the times at which the different species attain their peak standing crops, the Minnesota prairie might have shown an annual growth of some 200$300 \mathrm{~g} / \mathrm{m}^{2}$.

Some important differences between the seasonal rates of growth, mortality, and disappearance on the Old Field are best shown graphically (Fig. 4). The majority of growth in the swales occurred during June and July, with a second smaller peak in late September-early October. The latter peak was probably related to the production of fall shoots by the grasses. This fall peak is absent from the growth histogram of the upland area but otherwise the seasonal distribution of production on the upland is similar to that of the swales. The rate of mortality on both upland and swale was highest in the latter part of the season, with the exception of a peak of short duration in late Juneearly July. The rate of disappearance varied the

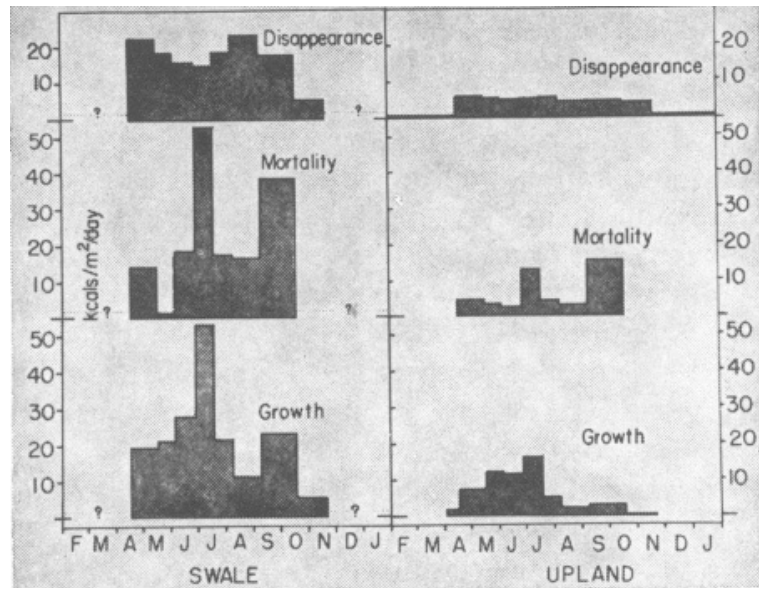

FIG. 4. Rates of growth and mortality of green vegetation and disappearance rate of dead material on Evans Old Field, 1960. Dotted lines with question marks indicate rates greater than zero throughout the year.

least of any parameter. Dead material disappeared at relatively high rates during the warm months and continued to disappear, but at a reduced rate, through the winter on the upland areas, and presumably also on the swales.

If information on the seasonal distribution of production is not needed, the net annual shoot growth (exclusive of herbivore consumption) can be estimated from data on only the standing crop of dead material and its rate of disappearance. If equation 6 is expanded and summed over any number of intervals, terms cancel and:

$$
\sum_{i=1}^{n} y_{i}=\left(b_{n}-b_{0}\right)+\left(a_{n}-a_{0}\right)+\sum_{i=1}^{n} x_{i}
$$

In relatively stable ecosystems $\left(b_{n}-b_{o}\right)$ and $\left(a_{n}-a_{o}\right)$ approximate zero and can be disregarded in calculating the net annual growth of vegetation. The latter is therefore equal to the amount of dead material disappearing per year. Because the standing crop of dead material fluctuates little during the year (Table I, Fig. 2), a few samples of dead material taken over the year should thus suffice to determine a mean standing crop of dead material. This value, multiplied by the annual instantaneous rate of disappearance for the year, gives the total of dead material disappearing per year.

For example, the mean standing crop of dead material over 1 year is computed as the mean standing crop over each interval, weighted for the relative length of the interval. The annual instantaneous disappearance rate is the sum of the daily rates for each interval, multiplied by the days in the interval. Thus, using the identities given earlier : 
Mean annual standing crop of dead

material $=\sum_{i=1}^{n} \frac{\left(a_{i-1}+a_{i}\right)}{2} \cdot \frac{t_{i}}{365}$

Annual instantaneous rate of

$$
\text { disappearance }=\sum_{i=1}^{n}\left(r_{i} \cdot t_{i}\right)
$$

The mean annual standing crop of dead material (eq. 8) was calculated for the upland portion of the Old Field in 1960 from the values in Table I. The annual instantaneous rate of disappearance (eq. 9) was obtained with the values in Table IV. Note that the intervals (values of $t_{i}$ ) are different in the two instances. In equation (9) the rates measured for 1960-61 were used, except that for the remaining 108-day period between $1 / 14$ and $5 / 2$ we used the value of $1.3 \mathrm{mg} / \mathrm{g}$ per day measured during 11/21-4/16, 1959-60.

The product of these two values $\left(195 \mathrm{~g} / \mathrm{m}^{2}\right.$ mean standing crop of dead material) and (1.72 $\mathrm{g} / \mathrm{g}$ per year disappearance rate) is $335 \mathrm{~g} / \mathrm{m}^{2}$ per year. This value differs little from the estimate of total growth obtained by summing the column for upland-1960 in Table VIII. Thus, where the simplifying assumptions can be justified, the shorter method can give accurate estimates of annual net growth of vegetation based only on a knowledge of the standing crop of dead material and its rate of disappearance.

\section{Primary production}

The primary production of photosynthetic organisms can be divided into a number of components. One of these, the respiratory energy loss of the plant biomass, will not be considered in this paper. Our discussion must therefore be confined to the topic of net primary production (gross primary production minus plant respiration).

In presenting a method for measuring the growth of the aboveground parts of the primary producers, we have ignored two other components of the net primary production: (1) the root growth, and (2) the consumption of green plant material by herbivores.

The standing crop of roots is expected to increase gradually during the growing season as a result of both the accumulation of stored products of photosynthesis and the growth of the roots. The peak standing crop of roots should therefore occur coincidentally with the maturation and death of the vegetation.

In southeastern Michigan, between mid-October and early May there is little growth of vegetation, and probably the production of roots is correspondingly low. Any attenuation of the standing crop of roots must be caused by their death and utilization by soil decomposer organisms. With the advent of active growth in the spring a certain portion of the remaining energy in the root biomass is used for the production of the first green shoots. The lowest standing crop of roots thus occurs when the rate of net photosynthesis first equals the rate of growth of the new shoot.

It was not possible to sample the root standing crop at intervals throughout the year, so October 18 was chosen as the date of the peak, and May 20 was chosen as the date of the lowest standing crop. The sampling data presented in Table III show that between these two dates, the root biomass on the Evans Old Field decreased by 143 $\mathrm{g} / \mathrm{m}^{2}$ on the upland and by $358 \mathrm{~g} / \mathrm{m}^{2}$ on the swales.

These values can only be regarded as minimum estimates of the annual root production since all the criticisms of the standing crop increment method given earlier in the paper are equally valid here. There is probably considerable attrition and replacement occurring in the root system, just as in the aboveground parts of the plant. There is at present no way of measuring this mortality that is analogous to the method for aboveground vegetation.

TABLE IX. Summary of net production ${ }^{1}$ by vascular plants on the Evans Old Field, 1959-60 (All values in $\mathrm{kcal} / \mathrm{m}^{2}$ per year.)

\begin{tabular}{|c|c|c|c|c|}
\hline \multirow{2}{*}{ Item } & \multicolumn{2}{|c|}{ Upland } & \multicolumn{2}{|c|}{ Swale } \\
\hline & 1959 & 1960 & 1959 & 1960 \\
\hline $\begin{array}{l}\text { Shoots.. } \\
\text { Roots }^{2} \text {. }\end{array}$ & $\begin{array}{r}1,328 \\
631\end{array}$ & $\begin{array}{r}1,392 \\
631\end{array}$ & $\begin{array}{l}4,102 \\
1,573\end{array}$ & $\begin{array}{l}4,629 \\
1,573 \\
\end{array}$ \\
\hline Net production. & 1,959 & 2,023 & 5,675 & 6,202 \\
\hline
\end{tabular}

1Values do not include herbiv re consumption 21960-61 root data used for both years.

Table IX summarizes the data on net primary production in 1959 and 1960 on both the upland and swales. The total energy of growth is the sum of shoot production and root production.

If the data from the root standing crop samples are presumed to give at least a minimum estimate of the production associated with the root biomass, then the net primary production on the upland is approximately $2,000 \mathrm{kcal} / \mathrm{m}^{2}$ per year versus approximately $6,000 \mathrm{kcal} / \mathrm{m}^{2}$ per year on the swales.

The total energy ingested by the herbivores on the Old Field is unknown. Whitetail deer (Odocoileus) occasionally graze on the field, numbers of striped ground squirrels (Citellus) are present in most years, and the swales occasionally support small populations of voles (Microtus or Synapto$m y s)$. No data are available on the energy in- 
gested by these groups. However, it is likely that their consumption is small compared to that of the insects. During 1959 and 1960, the senior author studied the energetics of the spittlebug (Philaenus) and grasshopper populations on the Old Field. These two groups account for approximately $90 \%$ of the biomass of aboveground insects, excluding ants, yet together they ingest less than $1 \%$ of the net primary production. Thus, the estimates of net primary production given in Table IX are probably not greatly different from the true values, were the total herbivore consumption known.

Because of the difficulties of measuring the root growth, together with the importance of the root biomass as a receptacle for much of the annual photosynthetic product of the Old Field vegetation (Table IX), we think that the major source of error in the study of net primary production of terrestrial ecosystems arises not so much from a lack of information about consumption by primary consumers, as from ignorance of the dynamic processes associated with the subterranean parts of the plant community.

\section{SUMMARY}

During the period 1949-60 the flora of a longabandoned field in southeastern Michigan showed little change. The peak standing crop of vegetation remained relatively constant from year to year, but during this period grasses decreased in importance from more than $90 \%$ of the standing crop biomass to less than $50 \%$.

Because of the diverse perennial flora of the Old Field, the peak standing crop was not a good indication of annual net production. Instead, the annual disappearance of dead material was equated with the net annual growth, exclusive of herbivore consumption.

Dead material in place on the field disappeared at rates of from 8.4 to $1.3 \mathrm{mg} / \mathrm{g}$ per day on the upland and 13.6 to $1.8 \mathrm{mg} / \mathrm{g}$ per day on the swales, depending on time of year. Material placed in mesh bags did not disappear as fast as undisturbed material, even after being on the field 6 months. But the mesh-bag experiments showed that the rate of disappearance did differ with species of plant during the first 2 months after placement, but not thereafter.

The rates of disappearance of dead material, combined with data on green and dead standing crops, were used to calculate net production of the aboveground plant parts and its seasonal distribution in 1959 and 1960. In 1959, shoot production on the Old Field was: upland, $1,328 \mathrm{kcal} / \mathrm{m}^{2}$; swale, $4,102 \mathrm{kcal} / \mathrm{m}^{2}$. In 1960 the corresponding values were: upland, $1,392 \mathrm{kcal} / \mathrm{m}^{2}$ and swale, 4,629 . The net annual production of root biomass in 1960 was minimally estimated as $631 \mathrm{kcal} / \mathrm{m}^{2}$ on upland and $1,573 \mathrm{kcal} / \mathrm{m}^{2}$ on the swales.

Net production of the vegetation in 1960 (exclusive of herbivore consumption but including root production) thus was estimated as 2,023 $\mathrm{kcal} / \mathrm{m}^{2}$ on upland and $6,202 \mathrm{kcal} / \mathrm{m}^{2}$ on the swales.

Because of the greater quantitative importance of root growth as compared to the amount of herbivore consumption, lack of detailed information about the latter is less an obstacle to the correct estimation of annual net production of vegetation than is the present ignorance of the dynamic processes associated with the subterranean parts of the plant community.

\section{ACKNOWLEDGMENTS}

The paired-plot method of measuring disappearance rates was suggested to us by D. W. Hayne, U. S. Fish and Wildlife Service, Patuxent Research Refuge, Laurel, Md. Assistance in collecting data on standing crops for the years 1949-59 was given by R. H. Brand, V. Brookes, R. D. Ivey, U. N. Lanham, B. C. Patten, and D. L. Riggs. Funds for travel and subsistence were provided by the University of Michigan's Horace H. Rackham Graduate Student Research Fund, by the Edwin S. George Reserve Scholarship Fund, and in 1960-61 by a pre-doctoral fellowship awarded to the senior author by the National Science Foundation. The study was also supported, for the period 1949-56, by the Laboratory of Vertebrate Biology, then under the direction of L. R. Dice, and subsequently under the Department of Zoology, University of Michigan. Support for the preparation of the manuscript was received from the U. S. Atomic Energy Commission, under contract AT (07-2) -10 to the University of Georgia.

\section{Literature Cited}

Evans, F. C., and S. A. Cain. 1952. Preliminary studies on the vegetation of an old-field community in southeastern Michigan. Cont. Lab. Vert. Biol. 51: 1-17.

Evans, F. C., and E. Dahl. 1955. The vegetational structure of an abandoned field in southeastern Michigan and its relation to environmental factors. Ecology 36: 685-706.

Golley, F. B. 1961. Energy values of ecological materials. Ecology 42: 581-584.

Odum, E. P. 1960. Organic production and turnover in old field succession. Ecology 41: 34-49.

Ovington, J. D., D. Heitkamp, and D. Lawrence. 1963. Plant biomass and productivity of prairie, savannah, oakwood and maize field ecosystems. Ecology 44: 52-63.

Richman, S. 1958. The transformation of energy by Daphnia pulex. Ecol. Monographs 28: 273-291.

Siegel, S. 1956. Non-parametric statistics for the behavioral sciences. McGraw-Hill, Inc., New York. $312 \mathrm{p}$.

Snedecor, G. W. 1956. Statistical methods. The Iowa State College Press, Ames, Iowa. 534 p.

Weaver, J. E. 1958a. Classification of root systems of forbs of grassland and a consideration of their significance. Ecology 39: 393-401. 
1958b. Summary and interpretation of underground development in natural grassland communities. Ecol. Monographs 28: 55-78.
Wiegert, R. G. 1962. The selection of an optimum quadrat size for sampling the standing crop of grasses and forbs. Ecology 43: 125-129.

\title{
ROOT DEVELOPMENT OF NATIVE PLANTS UNDER THREE GRAZING INTENSITIES'
}

\author{
JOSEPH L. SCHUSTER ${ }^{2}$ \\ Southern Forest Experiment Station, U.S. Forest Service \\ Nacogdoches, Texas
}

The purpose of this study was to determine the effects of various intensities of grazing upon roots and root systems of plants native to the ponderosa pine zone of the Colorado Front Range. It was designed to ascertain the root characteristics of certain species of the plant community and any changes in root distribution induced by 17 years of moderate and heavy grazing by cattle. The cumulative effects of such grazing are also illustrated.

Most studies concerning the effects of plant defoliation show that any cropping (clipping or grazing) reduces plant growth, especially root growth. The initial root and rhizome response to defoliation is the cessation of elongation (Parker and Sampson 1931, Crider 1955). Subsequent reactions to continued defoliation are reduction in root numbers and branching (Jacques 1937, A1bertson, Riegel, and Launchbaugh 1953), root diameter (Biswell and Weaver 1933), and depth of soil penetration (Ruby and Young 1953, Cook, Stoddart, and Kinsinger 1958). The amount of reduction is directly related to the severity and frequency of defoliation (Graber 1931, Albertson et al. 1953, Thaine 1954). In general the degree of defoliation is more detrimental to root growth than frequency of defoliation. Crider (1955) showed that apical growth of grass roots stopped within $24 \mathrm{hr}$ after the removal of $40 \%$ or more of the foliage in one operation. The time required for roots to resume growth varied directly with the degree of foliage removal.

The consequences of overgrazing are apparently carried over from season to season. Weaver

\footnotetext{
${ }^{1}$ Based on a thesis submitted to the Graduate School of Colorado State University, Fort Collins, Colorado. The investigation was cooperative between Colorado State University and the Rocky Mountain Forest and Range Experiment Station, Forest Service, U. S. Department of Agriculture, Fort Collins, Colorado.

${ }^{2}$ The author acknowledges the invaluable guidance and assistance of C. H. Wasser, Dean of the College of Forestry, Colorado State University, who supervised the study. Thanks are also due the members of my graduate committee: D. S. Romine, L. D. Love, D. R. Smith, F. C. Daugherty, and D. F. Hervey, and to personnel at the Manitou Experimental Forest who assisted with the field work.
}

(1950) and Tomanek and Albertson (1957) found that continued overgrazing not only reduces the number, size, and extent of underground parts of the individual plants, but also brings about changes in species composition, from tall grasses to short grass.

\section{Study Area}

The study area was a typical ponderosa pinebunchgrass range located on the Manitou Experimental Forest, 28 miles northwest of Colorado Springs, Colorado. It has a gentle east-facing slope $(20 \%$ or less) with low ridges that run east and west. Elevations range from $7,600 \mathrm{ft}$ on the east to $8,200 \mathrm{ft}$ on the west. Cold winters with little snow and mild summers prevail. Annual precipitation has ranged from 8 to 23.5 in., and averages 15.3 in. Three-fourths of the yearly precipitation falls as rain from April through September.

Surface soils, normally about 12 to 18 in. deep, are reddish brown, sandy loams or loams, low in organic matter, and slightly acid. Subsoils are mostly sandy loams or sandy clay loams that grade into the unconsolidated gravelly parent material at varying depths of 10 to 62 in.

Four vegetation types occur on the experimental area (Johnson 1953) : grassland parks, open timber, dense timber, and abandoned fields. Ponderosa pine (Pinus ponderosa Lawson) is dominant in the overstory. The most important forage species are mountain muhly (Muhlenbergia montana (Nutt.) Hitchc.) and Arizona fescue (Festuca arizonica Vasey). Other species of importance are blue grama (Bouteloua gracilis (H.B.K.) Lag.), sedges (Carex spp.), fringed sagebrush (Artemisia frigida Willd.), RockyMountain pussytoes (Antennaria aprica Greene), cinquefoil (Potentilla spp.), and Fendler sandwort (Arenaria fendleri A. Gray). Mountain muhly and Arizona fescue produced the most cover in ungrazed exclosures and progressively less on moderately and heavily grazed ranges. In contrast, the cover of less desirable species such as Rocky Mountain pussytoes was as much or greater in heavily or 